\title{
Lung cancer mortality among workers making lead chromate and zinc chromate pigments at three English factories
}

\author{
JOAN M DAVIES \\ From the Institute of Cancer Research, Division of Epidemiology, Sutton, Surrey SM2 5PX, UK
}

ABSTRACT Lung cancer mortality among 1152 men working at three English chromate pigment factories was studied from the 1930s or 1940s until 1981. Workers at factory C were exposed only to lead chromate and experienced normal mortality (Obs/Exp deaths 7/6.45). Workers at factories $\mathrm{A}$ and $\mathrm{B}$ were exposed to both lead and zinc chromate; mortality was normal among those who had only low exposure $(\mathrm{O} / \mathrm{E} 7 / 6 \cdot 95)$. For workers with high or medium exposure lung cancer mortality was significantly raised among men remaining at least a year after entering service at factory A during 1932-54 (O/E 21/9.45) and at factory B during 1948-67 (O/E $11 / 2 \cdot 50)$. At factory A, 1933-46 entrants staying only 3-11 months were not affected $(\mathrm{O} / \mathrm{E}$ $6 / 5 \cdot 04)$ and 1955-63 entrants also appeared unaffected $(O / E 2 / 2 \cdot 00)$; working conditions there improved in 1955. The hazard at factories A and B affected workers who left after one year as well as those with longer service, and latent intervals were unusually short. The results indicate that moderate or heavy exposure to zinc chromate may give rise to a severe risk of developing lung cancer, but that exposure which is relatively mild or lasts less than a year may not constitute an effective risk. The results provide no indication that lead chromate induces lung cancer in man, even under conditions conducive to lead poisoning.

Numerous studies have examined the hazard of lung cancer recognised to exist at factories processing chromite ore to produce chromates. ${ }^{2}$ In 1950 Baetjer ${ }^{3}$ first drew attention to a German report ${ }^{4}$ of eight cases of lung cancer at three small plants using chromates to produce lead and zinc chromate pigments; the affected men had been employed for from five to 17 years, and four were aged under 40 at death. The German health authorities officially recognised lung cancer as an occupational disease of chromate pigment makers in $1943 .{ }^{4}$

In 1975 Langard and Norseth reported three cases of lung cancer among 133 employees of a small Norwegian firm producing zinc chromate pigments ${ }^{5}$; all three belonged to a subgroup of 24 men employed at least three years, with a total of only 0.079 cases expected. By 1983 six cases had occurred among these 24 men $(0 \cdot 135$ expected $)$, and one among the other 109 workers. ${ }^{6}$ Since 1975 excesses of lung cancer have been reported at plants produc-

Received 1 August 1983

Accepted 10 October 1983 ing lead and zinc chromate pigments in the United States, ${ }^{7}$ France, ${ }^{8}$ Germany, and the Netherlands; ${ }^{9}$ the United States plant was also one of three covered in unpublished studies. The Norwegian results suggest that zinc chromate is carcinogenic, but the published studies do not permit conclusions about lead chromate because all the lead chromate workers studied were also exposed to zinc chromate.

The present report provides detailed updated results of an English study, previously reported briefly, ${ }^{1011}$ initiated by industry in 1975 to ascertain whether the production of chromate pigments had posed a risk of developing lung cancer; there were then no indications as to whether or not English workers had been at risk. The report deals mainly with respiratory cancer; mortality from other cancers and non-malignant diseases will be reported later, and workers with clinical lead poisoning have already been followed up. ${ }^{12}$ The study covers three factories that accounted for much of the production of chromate pigments in England. Factory A closed in 1982 and factory B in 1978, but factory C is still operating. Workers exposed only to lead chromate 
(at $\mathrm{C}$ ) are distinguished from those also exposed to zinc chromate (at A and B), and lung cancer mortality is examined from the 1930s or 1940s until 1981 in relation to date and duration and severity of exposure.

Basic materials and processes were similar at all three factories and changed little during the study period. Lead had at times been bought in the form of litharge, but mainly as metal, and lead nitrate or acetate produced in the factory "lead plants" was reacted with sodium chromate or dichromate. Although once bought as crystals, sodium dichromate was more recently used in liquor form. To make zinc chromate, zinc oxide powder was reacted with chromic acid or sodium dichromate. The precipitates were washed, filtered, and stove dried in "wet" departments, and then ground, blended, and packed in "dry" departments, where the conditions were dustiest. Sporadic clouds of dust also occurred in the wet departments, and deposit might dry on workshop surfaces and on operatives' clothing. Respirators provided for dusty jobs were not worn consistently until relatively recently. Airborne chromium measurements have only recently been available and have little relevance to the study period. Conditions at all three factories used to be such that episodes of lead poisoning were common; up to around 1945 at factory $A$ and around 1959 at $\mathrm{B}$ and $\mathrm{C}$ about one worker in 12 was affected during his employment. ${ }^{12}$ The work was mostly unskilled or semiskilled, heavy and dirty. Labour turnover was high, and broken service common; managements could not be as selective when engaging new operatives as employers offering more attractive work.

Chromate pigments had been made since before 1920 at factory A, which in 1977 employed about 100 operatives. Both lead and zinc chromates were produced, and also small amounts of barium chromate from 1942. Zinc chromate production ceased in 1964; it had previously accounted for about $6-12 \%$ of production. In earlier years organic pigments had also been made, and until 1937 a range of finished paints. In 1955 an isolated case of lead poisoning led to stricter control of dust exposures, with increased use of respirators, improvements in packaging procedures, and stricter monitoring of workers' lead absorption.

At factory B lead chromate pigments had been made since the 1920s. Zinc chromate was first made on a small scale in about 1938; after 1949 its share of production was about $10 \%$, rising to $50 \%$ after 1968. At that date a new, separate zinc chromate plant was built with a spray drier replacing the dusty stove drying process, and a more efficient dust extraction system was installed in the dry department. Until 1970 there were 70-80 manual workers, but later only about 50 . From the early 1950 s until about 1968 small amounts of strontium chromate were produced, but totalled only about 20 tons in all.

Factory C employed about 50 operatives in 1977; lead chromate pigments had been made from 1929 and were always virtually the only products. Output increased steadily until 1970 , but later declined. In 1950 the dry department was reorganised and dust extraction improved; in 1972 a spray drier largely replaced the dusty drying and powdering operations and other improvements were made.

At factory A until 1964 and factory B until 1968 virtually all workers had mixed exposures to lead chromate and zinc chromate, which were processed in the same shops, but those at factory $\mathrm{C}$ had no exposure to zinc chromate. Workers at factory B from the 1950 s to 1968 could also have had slight exposure to strontium chromate.

\section{Methods}

\section{NOMINAL ROLL}

The study covers all male workers (except office staff) completing at least one year's service by 30 June 1975 from as early a date as records permitted. Men with broken service are included if their total service lasted 365 days or longer. Managements abstracted workers' identifying and job details from personnel records, and these were checked and amplified as necessary by the author, who had free access to all factory records.

Table 1 shows the "earliest dates" from which records of leavers had been retained at each factory; all entrants staying at least 12 months could be included from the previous year onwards. At each factory there were also groups of "early entrants" already in service long before the earliest dates, including some who had joined as long as 20 years previously. At factory A a group of 97 "short service" men entering during 1933-46 but staying only 3-11 months was also included.

The completeness of the personnel records and nominal rolls at each factory was carefully checked by reference to other available records including medical records, health and general factory registers, and pay and insurance records. At factory $B$ the details for some included workers were scanty. One worker at factory $\mathrm{C}$ was excluded because he had previously worked with zinc chromate for about 15 years at another firm; he died from lung cancer within two years of joining factory $C$ (case 04 ).

Workers' identifying details were referred to the National Health Service Central Register (NHSCR) for the men to be identified, traced, and flagged, and for notification of all deaths. Immigrants apart, 38 
men were initially unidentified or untraced, but eventually all but five were traced-one short service worker and two post-1967 entrants at factory $A$, a pre-1948 entrant at B, and a 1961 entrant at C; except for the last man these were in groups of minor interest, and all five have been excluded from the analysis. Thirty one men emigrated and were removed from observation at their dates of embarkation: 22 from factory $A$, three from $B$, and six from C.

Immigrant workers may present identification problems for the NHSCR, and some may leave the country again. Nine West Indians took jobs at factory B during 1962-4, but all left within four years. Three were untraced, and all nine have been excluded from the analysis; no deaths have been reported among the six men identified by the NHSCR. It will be seen that the exclusion of these men can scarcely influence the factory $B$ results.

At factory $C$ West Indian and Asian immigrants have formed a gradually increasing proportion of the unskilled workforce since 1956. Eighteen West Indians entered service during 1956-60; two were not identified in NHSCR records and are excluded from the analysis. Thirty eight immigrants (predominantly West Indians) entered during 1961-7; four remained unidentified or untraced and are excluded.
Most of the 36 immigrants who joined during 1968 to mid-1974 were Asians, and 10 had to be excluded, but these late entrants are of only peripheral interest in the present analysis. Five deaths have been notified among the 76 immigrants traced by the NHSCR; none has been due to lung cancer.

\section{SUBDIVISIONS OF THE STUDY POPULATION Date of entry}

The main study groups at each factory comprise complete cohorts of men entering service between the earliest dates and 1967 and remaining at least one year. Table 2 shows the predetermined date definitions of different entry cohorts chosen to correspond to significant dates. "Early entrants" form a biased group of less interest since they are available for study only by virtue of long service, most of their contemporary workmates being unavailable because they left before records of leavers were systematically retained. "Late entrants" joining after 1967 are at present of minor interest on account of their short follow up period.

\section{Duration of service}

Predetermined divisions were used: 3-11 months (factory A), one complete year, 2-4 years, 5-9

Table 1 Total numbers of men available for study

\begin{tabular}{|c|c|c|c|c|}
\hline \multirow[t]{2}{*}{ Groups } & \multicolumn{3}{|c|}{ Factories } & \multirow[b]{2}{*}{ Total } \\
\hline & $A$ & $B^{*}$ & $C$ & \\
\hline $\begin{array}{l}\text { Earliest dates from which records listed all men including leavers } \\
\text { Early entrants already in service before the earliest dates } \\
\text { Main study groups entering from the earliest dates up to } 1967 \\
\text { Late entrants entering from } 1968 \text { to mid-1974 } \\
\text { "Short service" workers entering } 1933-46 \text { and staying 3-11 months } \\
\text { Total }\end{array}$ & $\begin{array}{r}1933 \\
85 \\
411 \\
82 \\
97 \\
675\end{array}$ & $\begin{array}{r}1949 \\
57 \\
138 \\
27 \\
222\end{array}$ & $\begin{array}{l}1947 \\
47 \\
167(50) \dagger \\
41(26) \dagger \\
2 \overline{255}(76) \dagger\end{array}$ & $\begin{array}{r}189 \\
716 \\
150 \\
97 \\
1152\end{array}$ \\
\hline
\end{tabular}

*Excluding nine West Indian immigrants.

†West Indian and Asian immigrants included.

Table 2 Subdivisions of the main study groups

\begin{tabular}{|c|c|c|c|c|c|c|c|}
\hline \multirow[t]{2}{*}{ Factory } & \multirow[t]{2}{*}{ Entry dates } & \multirow[t]{2}{*}{ Significance of closing date } & \multirow{2}{*}{$\begin{array}{l}\text { Years of } \\
\text { follow up }\end{array}$} & \multirow{2}{*}{$\begin{array}{l}\text { Total } \\
\text { men }\end{array}$} & \multicolumn{3}{|c|}{ Exposure grade } \\
\hline & & & & & High & Medium & Low \\
\hline $\mathbf{A}$ & $\begin{array}{l}1933-46 \\
1932-45 \\
1946-54 \\
1955-\text { mid-1963 } \\
\text { mid-1963-1967 }\end{array}$ & $\begin{array}{l}\text { Short service workers } \\
\text { End of second world war } \\
\text { Factory improvements } \\
1 \text { year before end of zinc chromate production } \\
\text { Minimum } 14 \text { years' observation }\end{array}$ & $\begin{array}{l}35-48 \\
36-49 \\
27-35 \\
18-26 \\
14-17\end{array}$ & $\begin{array}{r}97 \\
158 \\
103 \\
107 \\
43\end{array}$ & $\begin{array}{r}31 \\
30 \\
22 \\
6\end{array}$ & $\begin{array}{l}72 \\
47 \\
68 \\
24\end{array}$ & $\begin{array}{l}55 \\
26 \\
17 \\
13\end{array}$ \\
\hline $\mathbf{B}$ & $\begin{array}{l}1948-60 \\
1961-67\end{array}$ & $\begin{array}{l}\text { Min } 21 \text { years' observation } \\
\text { Factory improvements }\end{array}$ & $\begin{array}{l}21-35 \\
14-20\end{array}$ & $\begin{array}{l}79 \\
59\end{array}$ & $\begin{array}{l}25 \\
13\end{array}$ & $\begin{array}{l}42 \\
38\end{array}$ & $\begin{array}{r}12 \\
8\end{array}$ \\
\hline C & $\begin{array}{l}1946-60 \\
1961-67\end{array}$ & $\begin{array}{l}\text { Min } 21 \text { years' observation } \\
\text { Min } 14 \text { years' observation }\end{array}$ & $\begin{array}{l}21-35 \\
14-20\end{array}$ & $\begin{array}{l}97(16) \dagger \\
70(34) \dagger\end{array}$ & $\begin{array}{l}24 \\
13\end{array}$ & $\begin{array}{l}59 \\
51\end{array}$ & $\begin{array}{r}14 \\
6\end{array}$ \\
\hline
\end{tabular}

+West Indian and Asian immigrants included. 
years, and 10 or more years; with broken service the days in each spell were summed.

\section{Exposure grade}

At each factory jobs were allocated to exposure grades in discussion with managements. The "high" grade covered jobs in dry departments and full time stove drying, which entailed prolonged, heavy exposure to chromate containing dust. By contrast "low" grade jobs entailed only slight or occasional exposure to chromate, and included most managerial and laboratory jobs; work in shops where chromates were not processed; jobs mainly outside on maintenance painting, bricklaying, and carpentry; and work as stoker, watchman, etc. All other jobs were graded "medium", including those in wet departments, certain warehouse work, and the jobs of men going all over the factories-maintenance fitters, greasers and electricians, yard gangs and forklift drivers, and "cleaners" at factory B. At factory B many men's jobs were not recorded and were supplied from memory; seven men's jobs remained unknown and were graded medium.

Most workers changed jobs during their service; about 200 men had jobs in different grades, and these were allocated an overall grading designed to retain relatively undiluted high and low grades. An overall high grade was restricted to men spending at least half their service (and not less than one year) in high exposure jobs, and an overall low grade was reserved for those spending substantial proportions of their service in low exposure jobs. The medium overall grade not only covered men spending most time in medium exposure jobs, but was also a com- promise overall grade for those with mixed high/low or high/medium/low exposures. For long service men the overall grade was based on their first 10 years' work.

\section{METHODS OF ANALYSIS}

Entry into observation occurred after completion of 365 days service for most men, but 365 days after entry for short service workers, and for early entrants was on 1 January 1933 at factory A, 1 January 1949 at B, and 1 January 1947 at C. Manyears at risk until death, emigration, or 31 December 1981 were calculated in the usual quinary quinquennial age and date groupings, and were analysed simultaneously by duration of service and by five year intervals after starting service.

Expected numbers of deaths were obtained by use of specially compiled quinary quinquennial national death rates covering 1931-5 onwards; 1976-80 rates were used for 1981. As discussed later, these rates were not adjusted for regional or social class factors. In the analyses "lung cancer" is defined by ICD codes 162-165, "larynx cancer" by ICD 161 , and "cancer of the nose and nasal sinuses" by ICD 160 (9th revision) $)^{13}$ and earlier equivalents. The appendix table gives details of all deaths from respiratory cancer; all those in ICD codes 162-165 were described on the death certificates as cancers of the lung or bronchus. Non-malignant respiratory diseases are defined by ICD codes 460-519 (9th revision).

Lung cancer results are presented as observed/ expected $(\mathrm{O} / \mathrm{E})$ numbers of deaths and ratios, and 95\% confidence intervals $(\mathrm{CI})$ assuming a Poisson

Table 3 Observed and expected deaths from all causes except lung cancer, other respiratory cancers, and non-malignant respiratory diseases

\begin{tabular}{|c|c|c|c|c|c|c|}
\hline \multirow[t]{2}{*}{ Factory and entry cohort } & \multirow{2}{*}{$\begin{array}{l}\text { No of men and } \\
\text { man-years }\end{array}$} & \multicolumn{2}{|c|}{ All causes except lung cancer } & \multicolumn{2}{|c|}{ Non-malignant respiratory diseases } & \multirow{2}{*}{$\begin{array}{l}\text { Other respiratory } \\
\text { cancers } \\
\text { Obs/Exp }\end{array}$} \\
\hline & & $O b s / E x p$ & Ratio & $O b s / E x p$ & Ratio & \\
\hline $\begin{array}{l}\text { Factory } A \\
\text { Pre-1932 } \\
\text { Short-service: } \\
1933-46 \\
1932-45 \\
1946-54 \\
1955-\text { mid-1963 } \\
\text { Mid-1963-1967 } \\
\text { Total }\end{array}$ & $\begin{array}{c}85 / 2747 \\
\\
97 / 3332 \\
158 / 5399 \\
103 / 2645 \\
107 / 2092 \\
43 / 643 \\
593 / 16858\end{array}$ & $\begin{array}{c}60 / 53 \cdot 74 \\
41 / 43 \cdot 94 \\
74 / 69 \cdot 57 \\
29 / 33 \cdot 27 \\
14 / 18 \cdot 25 \\
3 / 3 \cdot 28 \\
221 / 222 \cdot 05\end{array}$ & $\begin{array}{l}1.12 \\
0.93 \\
1.06 \\
0.87 \\
0.77 \\
0.91 \\
1.00\end{array}$ & $\begin{array}{c}13 / 9 \cdot 56 \\
6 / 6 \cdot 72 \\
13 / 10 \cdot 60 \\
8 / 5 \cdot 00 \\
2 / 2 \cdot 39 \\
2 / 0 \cdot 34 \\
44 / 34 \cdot 61\end{array}$ & $\begin{array}{l}1.36 \\
0.89 \\
1.23 \\
1.60 \\
0.84 \\
5.88 \\
1.27\end{array}$ & $\begin{array}{l}1 / 0.19 \\
0 / 0.15 \\
1 / 0.24 \\
0 / 0.11 \\
0 / 0.06 \\
0 / 0.01 \\
2 / 0.76\end{array}$ \\
\hline $\begin{array}{l}\text { Factory B } \\
\text { Pre-1948 } \\
1948-60 \\
1961-67 \\
\text { Total }\end{array}$ & $\begin{array}{c}57 / 1360 \\
79 / 1777 \\
59 / 885 \\
195 / 4022\end{array}$ & $\begin{array}{c}30 / 23 \cdot 16 \\
15 / 13 \cdot 02 \\
5 / 7 \cdot 64 \\
50 / 43 \cdot 82\end{array}$ & $\begin{array}{l}1.30 \\
1 \cdot 15 \\
0.65 \\
1 \cdot 14\end{array}$ & $\begin{array}{l}2 / 3 \cdot 81 \\
3 / 1 \cdot 56 \\
0 / 0 \cdot 92 \\
5 / 6 \cdot 29\end{array}$ & $\begin{array}{l}0.52 \\
1.92 \\
0.00 \\
0.79\end{array}$ & $\begin{array}{l}0 / 0.08 \\
0 / 0.05 \\
0 / 0.03 \\
0 / 0 \cdot 16\end{array}$ \\
\hline
\end{tabular}



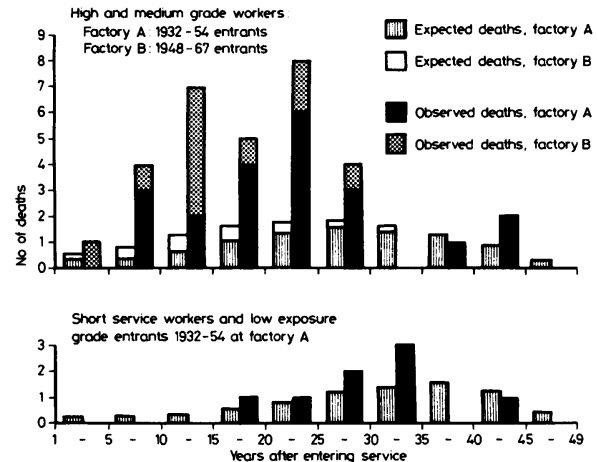

Expected and observed lung cancer deaths by interval after entering service.

distribution ${ }^{14}$; where the $\mathrm{CI}$ does not include 1.0 the, $\mathrm{O} / \mathrm{E}$ difference is significant at the $5 \%$ probability level. The results for factory $A$ indicated that a division before and after 30 years from entry into service defined the period of maximum risk. This division is made in most tables, but it was chosen with hindsight, and significance testing is restricted to undivided results for the total observation period except in tables 7 and 8.

\section{Results}

Table 3 shows results for three groups of causes; none of the $\mathrm{O} / \mathrm{E}$ differences is statistically significant. Mortality from all causes except lung cancer appears generally low at factory C, but only appears low for entrants after 1945 at A, and for entrants after 1960 at $B$. The figures suggest a modest excess of deaths from non-malignant respiratory diseases at $\mathrm{A}$ and $\mathrm{C}$; the overall $\mathrm{O} / \mathrm{E}$ figures for all three factories are $62 / 50.53$, giving a ratio of 1.23 with a $95 \% \mathrm{CI}$ of $0 \cdot 9-1 \cdot 6$. The overall figures for "other respiratory cancers" are $3 / 1 \cdot 13$, ratio 2.65 , CI $0 \cdot 5-7 \cdot 7$. There were two deaths from laryngeal cancer versus 0.93 expected (cases 05 and 06 , a West Indian immigrant). The other death (case 07) was from cancer of the nasal sinuses (expected total $0 \cdot 20)$.

Table 4 gives lung cancer results for factory $\mathrm{A}$. Among workers with high and medium exposure mortality is significantly raised over the total follow up period among 1932-45 entrants (O/E ratio $2 \cdot 22)$, and a similar excess (O/E ratio $2 \cdot 23$ ) among 1946-54 entrants falls just short of significance; no excess is apparent among later entrants (total $\mathrm{O} / \mathrm{E}$ $2 / 2 \cdot 18$ ). There is no indication of excess lung cancer

Table 4 Observed and expected lung cancer deaths at factory $A$

\begin{tabular}{|c|c|c|c|c|c|c|c|}
\hline \multirow[t]{3}{*}{ Cohort and exposure grade } & \multirow[t]{3}{*}{ No of men } & \multicolumn{4}{|c|}{ Interval after entry } & \multirow{2}{*}{\multicolumn{2}{|c|}{ Total }} \\
\hline & & \multicolumn{2}{|l|}{$1-29$ years } & \multicolumn{2}{|l|}{$\geqslant 30$ years } & & \\
\hline & & Man-years & Obs/Exp & Man-years & $O b s / E x p$ & Obs/Exp & Ratio and $\mathrm{CI}^{*}$ \\
\hline $\begin{array}{l}\text { Early entrants } \\
\text { High and medium }\end{array}$ & 33 & 519 & $1 / 0 \cdot 24$ & 501 & $1 / 1 \cdot 85$ & $2 / 2 \cdot 09$ & $\begin{array}{l}0.96 \\
(0.1-3.5)\end{array}$ \\
\hline Low & 52 & 987 & $1 / 0 \cdot 38$ & 740 & $2 / 2 \cdot 33$ & $3 / 2 \cdot 70$ & $\begin{array}{l}1 \cdot 11 \\
(0 \cdot 2-3 \cdot 2)\end{array}$ \\
\hline $\begin{array}{l}\text { 1933-46 Short service } \\
\text { Workers }\end{array}$ & 97 & 2497 & $3 / 1.91$ & 835 & $3 / 3 \cdot 13$ & $6 / 5 \cdot 04$ & $\begin{array}{l}1 \cdot 19 \\
(0 \cdot 4-2 \cdot 6)\end{array}$ \\
\hline $\begin{array}{l}1932-45 \\
\text { High } \\
\text { Medium } \\
\text { Low }\end{array}$ & $\begin{array}{l}31 \\
72 \\
55\end{array}$ & $\begin{array}{r}770 \\
1781 \\
1429\end{array}$ & $\begin{array}{l}3 / 0.55 \\
7 / 1 \cdot 76 \\
0 / 0 \cdot 62\end{array}$ & $\begin{array}{l}283 \\
522 \\
614\end{array}$ & $\left.\begin{array}{l}0 / 1 \cdot 23 \\
3 / 2 \cdot 32 \\
1 / 1 \cdot 58\end{array}\right\}$ & $\begin{array}{r}13 / 5 \cdot 86 \\
1 / 2 \cdot 20\end{array}$ & $\begin{array}{l}2 \cdot 22 \\
(1 \cdot 2-3 \cdot 8) \\
0 \cdot 45 \\
(0 \cdot 0-2 \cdot 5)\end{array}$ \\
\hline $\begin{array}{l}1946-54 \\
\text { High } \\
\text { Medium } \\
\text { Low }\end{array}$ & $\begin{array}{l}30 \\
47 \\
26\end{array}$ & $\begin{array}{r}718 \\
1168 \\
592\end{array}$ & $\begin{array}{l}4 / 1 \cdot 13 \\
4 / 1 \cdot 87 \\
1 / 0 \cdot 41\end{array}$ & $\begin{array}{l}40 \\
95 \\
32\end{array}$ & $\left.\begin{array}{l}0 / 0 \cdot 15 \\
0 / 0.44 \\
0 / 0.08\end{array}\right\}$ & $\begin{array}{l}8 / 3 \cdot 59 \\
1 / 0 \cdot 49\end{array}$ & $\begin{array}{l}2 \cdot 23 \\
(1 \cdot 0-4 \cdot 4) \\
2 \cdot 04 \\
(0 \cdot 1-11 \cdot 3)\end{array}$ \\
\hline $\begin{array}{l}1955-\text { mid-63 } \\
\text { High } \\
\text { Medium } \\
\text { Low }\end{array}$ & $\begin{array}{l}22 \\
68 \\
17\end{array}$ & $\begin{array}{r}431 \\
1337 \\
324\end{array}$ & $\begin{array}{l}0 / 0 \cdot 32 \\
2 / 1 \cdot 68 \\
0 / 0 \cdot 30\end{array}$ & $\bar{z}$ & E & $\begin{array}{l}2 / 2 \cdot 00 \\
0 / 0 \cdot 30\end{array}$ & $\begin{array}{l}1 \cdot 00 \\
(0 \cdot 1-3 \cdot 6)\end{array}$ \\
\hline $\begin{array}{l}\text { Mid-1963-67 } \\
\text { High and medium } \\
\text { Low }\end{array}$ & $\begin{array}{l}30 \\
13\end{array}$ & $\begin{array}{l}451 \\
192\end{array}$ & $\begin{array}{l}0 / 0.18 \\
0 / 0.23\end{array}$ & - & 二 & $\begin{array}{l}0 / 0.18 \\
0 / 0.23\end{array}$ & \\
\hline
\end{tabular}

*95\% Confidence intervals. 
deaths among pre-1932 early entrants, low exposure grade workers at any date, or 1933-46 short service men; division of the latter into two groups of 49 men with minimal chromates exposure $(\mathrm{O} / \mathrm{E} 4 / 2 \cdot 23)$ and 48 men with relatively greater exposure $(\mathrm{O} / \mathrm{E} 2 /$ $2 \cdot 81)$ still gives no indication that exposure lasting less than one year posed a hazard. The high and medium grade 1932-45 entrants have been observed for 36-49 years; their excess deaths occurred during 1-29 years after first exposure (O/E 10/ $2 \cdot 31)$, and from 30 years onwards mortality appears normal $(\mathrm{O} / \mathrm{E} 3 / 3 \cdot 55)$.

No lung cancer deaths have so far occurred among post-1967 entrants at any factory; expected deaths among high and medium grade workers are 0.24 at $\mathrm{A}, 0 \cdot 15$ at $\mathrm{B}$, and $0 \cdot 11$ at $\mathrm{C}$ (excluding immigrants).

The results for factory $B$ show highly significant excesses of lung cancer deaths among high and medium grade workers entering service during 1948-67 (total O/E 11/2.50, p < 0.001) (table 5). Two deaths have occurred among all low exposure workers, compared with 1.03 expected; both men were early entrants starting service in 1941 and 1945 and working in the Prussian blue department where chromates were not used, but their earliest jobs were recalled from memory and they may possibly have spent some time working elsewhere in the factory (cases B4, B5).

The results for factory $\mathrm{C}$ show a pronounced contrast, with no excess deaths (table 6). For high and medium grade entrants during 1946-67 the O/E figures are only $1 / 3 \cdot 10$; if the early entrants are added the figures are 4/5.07. Observed deaths among low exposure workers total three compared with 1.38 expected; two of the affected men (cases C5, C7) were full time stokers with trivial exposure to chromates, and stokers generally appear to have raised lung cancer mortality. ${ }^{15}$
The lung cancer excess thus appears confined to high and medium grade workers entering factory $\mathrm{A}$ before 1955 and factory B before 1968, and subsequent analyses focus on the 298 men in these grades joining A during 1932-54 and B during 1948-67. At first sight the excess appears more severe at $B$ $(\mathrm{O} / \mathrm{E} 11 / 2 \cdot 50$, ratio $4 \cdot 40)$ than at $\mathrm{A}(\mathrm{O} / \mathrm{E} 21 / 9 \cdot 45$, ratio $2 \cdot 22$ ), but this difference is due partly to the longer follow up of 1932-45 entrants at A. Up to 30 years after entry the $\mathrm{O} / \mathrm{E}$ ratios are 4.44 at $\mathrm{B}, 4.33$ for 1932-45 entrants at $A$, and 2.67 for $1946-54$ entrants.

The figure compares expected and observed deaths for these workers in five year intervals after entry into service; for each interval the first column shows the deaths expected and the second shows those observed. Similar data are also shown for short service and low exposure grade entrants at $\mathbf{A}$ during 1932-54; for these groups the observed deaths total eight compared with 7.73 expected, and the temporal pattern of cases appears random and unremarkable. By contrast the high and medium grade workers' mortality is already significantly high during the first nine years after entry $(\mathrm{O} / \mathrm{E} 5 / 1 \cdot 25$, $\mathrm{p}$ $<0.05)$. The excess appears most pronounced between 10 and 24 years, and from 30 years onwards appears to have ceased $(\mathrm{O} / \mathrm{E} 3 / 4 \cdot 14)$. This is not the final picture, for by the end of 1981 only pre- 1952 entrants had completed 29 years' service, but recently notified 1982 deaths seem to confirm the pattern, with no further deaths from factory $A$ but two additional deaths among factory B workers, 24 and 26 years after entry (cases B17 and B18).

Table 7 analyses mortality simultaneously by duration of service and 10 year interval after entry into employment; workers contribute man-years to each successive duration of service category in turn until they leave employment, subsequently remain-

Table 5 Observed and expected lung cancer deaths at factory $B$

\begin{tabular}{|c|c|c|c|c|c|c|c|}
\hline \multirow[t]{3}{*}{ Cohort and exposure grade } & \multirow[t]{3}{*}{ No of men } & \multicolumn{4}{|c|}{ Interval after entry } & \multirow{2}{*}{\multicolumn{2}{|c|}{ Total }} \\
\hline & & \multicolumn{2}{|l|}{$1-29$ years } & \multicolumn{2}{|l|}{$\geqslant 30$ years } & & \\
\hline & & $\overline{\text { Man-years }}$ & Obs/Exp & Man-years & Obs/Exp & $\overline{O b s / E x p}$ & Ratio and $\mathrm{CI}^{*}$ \\
\hline $\begin{array}{l}\text { Early entrants } \\
\text { High and medium }\end{array}$ & 36 & 623 & $2 / 0.99$ & 223 & $1 / 0 \cdot 89$ & $3 / 1 \cdot 88$ & 1.60 \\
\hline Low & 21 & 334 & $2 / 0 \cdot 31$ & 183 & $0 / 0.49$ & $2 / 0 \cdot 80$ & $\begin{array}{l}2 \cdot 5 \\
(0 \cdot 3-9 \cdot 0)\end{array}$ \\
\hline $\begin{array}{l}1948-60 \\
\text { High } \\
\text { Medium } \\
1961-67\end{array}$ & $\begin{array}{l}25 \\
42\end{array}$ & $\begin{array}{l}557 \\
898\end{array}$ & $\begin{array}{l}2 / 0 \cdot 59 \\
4 / 1 \cdot 00\end{array}$ & $\overline{14}$ & $\overline{0 / 0.02}\}$ & $6 / 1 \cdot 61$ & $\begin{array}{l}3 \cdot 73 \\
(1 \cdot 4-8 \cdot 1)\end{array}$ \\
\hline $\begin{array}{l}\text { High } \\
\text { Medium }\end{array}$ & $\begin{array}{l}13 \\
38\end{array}$ & $\begin{array}{l}198 \\
557\end{array}$ & $\begin{array}{l}1 / 0 \cdot 16 \\
4 / 0 \cdot 73\end{array}$ & - & $-\quad\}$ & $5 / 0.89$ & $\begin{array}{l}5 \cdot 62 \\
(1 \cdot 8-13 \cdot 1)\end{array}$ \\
\hline Low & 20 & 429 & $0 / 0 \cdot 22$ & 6 & $0 / 0.01$ & $0 / 0.23$ & \\
\hline
\end{tabular}

*95\% Confidence intervals. 
Table 6 Observed and expected lung cancer deaths at factory $C$

\begin{tabular}{|c|c|c|c|c|c|c|c|}
\hline \multirow[t]{3}{*}{ Cohort and exposure grade } & \multirow[t]{3}{*}{ No of men } & \multicolumn{4}{|c|}{ Interval after entry } & \multirow{2}{*}{\multicolumn{2}{|c|}{ Total }} \\
\hline & & \multicolumn{2}{|l|}{$1-29$ years } & \multicolumn{2}{|l|}{$\geqslant 30$ years } & & \\
\hline & & Man-years & Obs/Exp & Man-years & Obs/Exp & Obs/Exp & Ratio and $\mathrm{CI}^{*}$ \\
\hline $\begin{array}{l}\text { Early entrants } \\
\text { High and medium }\end{array}$ & 33 & 576 & $3 / 0.84$ & 298 & $0 / 1 \cdot 13$ & $3 / 1 \cdot 97$ & $\begin{array}{l}1.52 \\
(0.3-4.4)\end{array}$ \\
\hline Low & 14 & 232 & $1 / 0 \cdot 38$ & 137 & $1 / 0.62$ & $2 / 1 \cdot 00$ & $2 \cdot 00$ \\
\hline $\begin{array}{l}1946-60 \\
\text { Immigrants, high and } \\
\text { medium } \\
\text { Others, high and medium }\end{array}$ & $\begin{array}{l}16 \\
67\end{array}$ & $\begin{array}{r}334 \\
1487\end{array}$ & $\begin{array}{l}0 / 0.27 \\
1 / 1.90\end{array}$ & $\overline{54}$ & $\overline{0 / 0} \cdot 18$ & $\begin{array}{l}0 / 0 \cdot 27 \\
1 / 2 \cdot 08\end{array}$ & $\begin{array}{l}0.48 \\
(0.0-2 \cdot 7)\end{array}$ \\
\hline Others, low & 14 & 352 & $1 / 0 \cdot 28$ & 19 & $0 / 0.04$ & $1 / 0 \cdot 32$ & $\begin{array}{l}3 \cdot 13 \\
(0 \cdot 1-17 \cdot 4)\end{array}$ \\
\hline $\begin{array}{l}\text { Immigrants, high and } \\
\text { medium } \\
\text { Others, high and medium } \\
\text { Others, low }\end{array}$ & $\begin{array}{r}34 \\
30 \\
6\end{array}$ & $\begin{array}{r}510 \\
488 \\
73\end{array}$ & $\begin{array}{l}0 / 0.40 \\
0 / 0.35 \\
0 / 0.06\end{array}$ & $\bar{z}$ & $\bar{z}$ & $\begin{array}{l}0 / 0.40 \\
0 / 0.35 \\
0 / 0.06\end{array}$ & \\
\hline $\begin{array}{l}\text { Total } \\
\text { Immigrants, high and } \\
\text { medium } \\
\text { Others, high and medium }\end{array}$ & $\begin{array}{r}50 \\
130\end{array}$ & $\begin{array}{r}844 \\
2551\end{array}$ & $\begin{array}{l}0 / 0.67 \\
4 / 3.09\end{array}$ & $\overline{352}$ & $\overline{0 / 1} \cdot 31$ & $\begin{array}{l}0 / 0.67 \\
4 / 4 \cdot 40\end{array}$ & 0.91 \\
\hline Others, low & 34 & 657 & $2 / 0 \cdot 72$ & 156 & $1 / 0.66$ & $3 / 1 \cdot 38$ & $\begin{array}{l}2 \cdot 17 \\
(0.4-6 \cdot 3)\end{array}$ \\
\hline
\end{tabular}

*95\% Confidence intervals.

Table 7 Observed and expected lung cancer deaths by duration of service and interval after entry. High and medium grade entrants during 1932-54 at factory A, 1948-67 at B

\begin{tabular}{|c|c|c|c|c|c|c|c|c|c|c|c|}
\hline \multirow{3}{*}{$\begin{array}{l}\text { Interval } \\
\text { after } \\
\text { entry }(y)\end{array}$} & \multirow{3}{*}{$\begin{array}{l}\text { Man- } \\
\text { years }\end{array}$} & \multicolumn{10}{|l|}{ Duration } \\
\hline & & \multicolumn{2}{|l|}{1 year } & \multicolumn{2}{|l|}{$2-4$ years } & \multicolumn{2}{|l|}{$5-9$ years } & \multicolumn{2}{|c|}{$\geqslant 10$ years } & \multicolumn{2}{|l|}{ Total } \\
\hline & & Obs/Exp & $\begin{array}{l}\text { Ratio and } \\
\mathrm{CI}^{*}\end{array}$ & $O b s / E x p$ & $\begin{array}{l}\text { Ratio and } \\
\mathrm{CI}^{*}\end{array}$ & Obs/Exp & $\begin{array}{l}\text { Ratio and } \\
\mathrm{CI}^{*}\end{array}$ & $O b s / E x p$ & $\begin{array}{l}\text { Ratio and } \\
\mathrm{CI}^{*}\end{array}$ & $O b s / E x p$ & $\begin{array}{l}\text { Ratio and } \\
\mathrm{CI}^{*}\end{array}$ \\
\hline $1-9$ & 2595 & $1 / 0.50$ & 2.00 & $1 / 0.43$ & $2 \cdot 33$ & $3 / 0.32$ & $9 \cdot 38$ & - & - & $5 / 1 \cdot 25$ & 4.00 \\
\hline $10-19$ & 2478 & $4 / 1.06$ & 3.77 & $2 / 0.71$ & $2 \cdot 82$ & $0 / 0.50$ & & $6 / 0.62$ & 9.68 & $12 / 2 \cdot 89$ & $\begin{array}{l}4 \cdot 15 \\
(2 \cdot 1-7 \cdot 2)\end{array}$ \\
\hline $20-29$ & 1573 & $7 / 1.34$ & $5 \cdot 22$ & $1 / 1.04$ & 0.96 & $2 / 0.67$ & 2.99 & $2 / 0.63$ & $3 \cdot 17$ & $12 / 3.68$ & $\begin{array}{l}3 \cdot 26 \\
(1 \cdot 7-5 \cdot 7)\end{array}$ \\
\hline \multicolumn{12}{|l|}{ Subtotal } \\
\hline $1-29$ & 6646 & $12 / 2 \cdot 90$ & $\begin{array}{l}4 \cdot 14 \\
(2 \cdot 1-7 \cdot 2)\end{array}$ & $4 / 2 \cdot 18$ & $\begin{array}{l}1.83 \\
(0.5-4 \cdot 7)\end{array}$ & $5 / 1 \cdot 49$ & $\begin{array}{l}3 \cdot 36 \\
(1 \cdot 1-7 \cdot 9)\end{array}$ & $8 / 1 \cdot 25$ & $\begin{array}{l}6 \cdot 40 \\
(2 \cdot 8-12 \cdot 6)\end{array}$ & $29 / 7 \cdot 82$ & $\begin{array}{l}3 \cdot 71 \\
(2 \cdot 5-5 \cdot 3)\end{array}$ \\
\hline $30-49$ & 953 & $0 / 0.97$ & & $1 / 1 \cdot 29$ & 0.78 & $2 / 1 \cdot 10$ & 1.82 & $0 / 0.81$ & & $3 / 4 \cdot 17$ & $\begin{array}{l}0 \cdot 72 \\
(0 \cdot 2-2 \cdot 1)\end{array}$ \\
\hline \multicolumn{12}{|l|}{ Total } \\
\hline $1-49$ & 7599 & $12 / 3 \cdot 87$ & $\begin{array}{l}3 \cdot 10 \\
(1 \cdot 6-5 \cdot 4)\end{array}$ & $5 / 3.47$ & $\begin{array}{l}1.44 \\
(0.5-3.4)\end{array}$ & $7 / 2 \cdot 59$ & $\begin{array}{l}2 \cdot 70 \\
(1 \cdot 1-5 \cdot 6)\end{array}$ & $8 / 2 \cdot 06$ & $\begin{array}{l}3 \cdot 88 \\
(1 \cdot 7-7 \cdot 6)\end{array}$ & $32 / 11.99$ & $\begin{array}{l}2 \cdot 67 \\
(1 \cdot 8-3 \cdot 8)\end{array}$ \\
\hline
\end{tabular}

*95\% Confidence interval.

ing in the category attained when leaving. For each duration of service category except that of 2-4 years there are significant excesses of deaths during 1-29 years after entry and over the total follow up period. The excesses appear most severe among the men completing 10 or more years' service, but the $95 \%$ confidence intervals for the $\mathrm{O} / \mathrm{E}$ ratios are wide, and the apparent variations in the results for different durations of service categories could be due to chance.

The final analyses relate to exposure grade. The data in tables 4 and 5 showed surprisingly little (if any) difference in risk between the high and medium grades, even though the absence of excess deaths in certain groups seems to indicate the relevance of exposure level. The data were therefore reanalysed 
Table 8 Lung cancer deaths during 1-29 years after entry in redefined exposure grades. 1932-54 entrants at factory $A$, 1948-67 entrants at B

\begin{tabular}{|c|c|c|c|c|c|c|c|}
\hline \multirow{3}{*}{$\begin{array}{l}\text { Redefined grades } \\
\text { Men with at least } \\
1 \text { year in jobs graded }\end{array}$} & \multirow{3}{*}{$\begin{array}{l}\text { No of men } \\
\text { and man- } \\
\text { years }\end{array}$} & \multicolumn{6}{|l|}{ Duration } \\
\hline & & \multicolumn{2}{|l|}{$1-4$ years } & \multicolumn{2}{|l|}{$\geqslant 5$ years } & \multirow{2}{*}{$\begin{array}{l}\text { Total } \\
\text { OIE }\end{array}$} & \multirow[b]{2}{*}{$\begin{array}{l}\text { Ratio and } \\
\mathrm{CI}^{*}\end{array}$} \\
\hline & & $O / E$ & $\begin{array}{l}\text { Ratio and } \\
\mathrm{CI}^{*}\end{array}$ & $O / E$ & $\begin{array}{l}\text { Ratio and } \\
\mathrm{CI}^{*}\end{array}$ & & \\
\hline \multirow{6}{*}{$\begin{array}{l}\text { High } \\
\text { Medium: total } \\
\text { Medium: } \\
\text { Process } \\
\text { Medium: } \\
\text { Maintenance } \\
\text { Medium: } \\
\text { Other } \\
\text { All grades }\end{array}$} & \multirow{6}{*}{$\begin{array}{r}123 \\
2795 \\
178 \\
4005 \\
131 \\
2907 \\
24 \\
540 \\
23 \\
558 \\
301 \\
6800\end{array}$} & $9 / 1 \cdot 80$ & \multirow{5}{*}{$\begin{array}{l}5 \cdot 00 \\
(2 \cdot 3-9 \cdot 5) \\
1 \cdot 94 \\
(0.7-4 \cdot 2) \\
2 \cdot 53 \\
(0.9-5 \cdot 5)\end{array}$} & $3 / 1 \cdot 20$ & \multirow{5}{*}{$\begin{array}{l}2 \cdot 50 \\
(0 \cdot 5-7 \cdot 3) \\
5 \cdot 88 \\
(2 \cdot 8-10 \cdot 8) \\
7 \cdot 29 \\
(2 \cdot 9-15 \cdot 0) \\
5 \cdot 36 \\
(1 \cdot 1-15 \cdot 7)\end{array}$} & $12 / 3 \cdot 00$ & \multirow{5}{*}{$\begin{array}{l}4 \cdot 00 \\
(2 \cdot 1-7 \cdot 0) \\
3 \cdot 34 \\
(1 \cdot 9-5 \cdot 4) \\
3 \cdot 90 \\
(2 \cdot 1-6 \cdot 7) \\
3 \cdot 16 \\
(0 \cdot 7-9 \cdot 2)\end{array}$} \\
\hline & & $6 / 3.09$ & & $10 / 1 \cdot 70$ & & $16 / 4 \cdot 79$ & \\
\hline & & $6 / 2 \cdot 37$ & & $7 / 0.96$ & & $13 / 3 \cdot 33$ & \\
\hline & & $0 / 0.39$ & & $3 / 0 \cdot 56$ & & $3 / 0.95$ & \\
\hline & & $0 / 0.33$ & & $0 \dagger / 0-18$ & & $0+/ 0.51$ & \\
\hline & & $15 / 4 \cdot 89$ & $\begin{array}{l}3.07 \\
(1 \cdot 7-5 \cdot 1)\end{array}$ & $13 / 2 \cdot 90$ & $\begin{array}{l}4 \cdot 48 \\
(2 \cdot 4-7 \cdot 7)\end{array}$ & $28 / 7 \cdot 79$ & $\begin{array}{l}3 \cdot 59 \\
(2 \cdot 4-5 \cdot 2)\end{array}$ \\
\hline
\end{tabular}

* $95 \%$ Confidence interval.

tOne death occurred in 1982 (case B18, employed 11 years).

using redefined and more sensitive criteria for the high and medium grades. The high grade was expanded to include all men working for at least one year in high exposure jobs, and the medium grade was subdivided; "medium process" covering men with at least one year in wet chromate processing work; "medium maintenance" including men working as fitters, greasers, or electricians for one year or longer; and "other medium" covering the remainder with at least one year in miscellaneous medium jobs. The new definitions exclude the seven men at factory B with unknown jobs, but include 10 men previously graded low. Table 8 shows the revised results. There remains little if any difference between the overall ("total") results for the high and medium grades or within the medium grade; a 1982 death in the other medium subdivision has recently been notified (case B18, employed 11 years). There may, however, be differences in relation to duration of service: among high exposure workers the excess appears worse for those employed less than five years, while for medium process workers it appears worse among men with longer service, and for maintenance and other medium workers the excess appears confined to those employed at least five years.

\section{Discussion}

The national lung cancer death rates used in this study were not adjusted for social class or area of residence. Most men with high and medium exposure were semiskilled (class IV), and as a group they are of somewhat lower than average class. National lung cancer rates for class IV men under 65 were slightly below the nationa! average in $1949-53,^{10}$ just above in $1959-63,{ }^{17}$ and $23 \%$ higher in 1970 $2 .{ }^{15}$ The expected numbers of deaths calculated for these grades thus involve a slight understatement over the past two decades. Accurate adjustment for social class is not feasible since the subsequent jobs (and hence the class) of men leaving the factories are unknown. Social class lung cancer differentials probably derive mainly from differences in smoking habits. No general information is available about the smoking habits of the workers studied, but it is unlikely that they smoked more than the average for their class since smoking was officially banned during work.

At factory A most workers lived in a county borough where published lung cancer death rates around $1951,{ }^{18} 1961,{ }^{19}$ and $1971^{20}$ were almost identical with national rates. Consequently, only the social class factor is relevant, and the understatement of expected deaths among postwar entrants is too slight to affect the trend of the results.

At factory B most workers lived in two small urban areas where unpublished data obtained by courtesy of the Office of Population Censuses and Surveys show that lung cancer death rates were respectively about $55 \%$ and $25 \%$ lower than national rates around 1961 , and about $30 \%$ and $12 \%$ lower around 1971 . Thus the area factor more than offsets the class factor, and the stated expected numbers of deaths at $B$ must be slightly overstated and the excess mortality slightly understated.

Most factory $\mathrm{C}$ workers lived in a London borough with lung cancer death rates about $50 \%$ higher than national rates around 1951 and 1961, and about $44 \%$ higher around $1971 . .^{18-20}$ It may be 
imprudent to treat the class and area factors as additive, but due to the area factor alone the stated expected deaths for factory $C$ workers (other than immigrants) have probably been understated by at least $40 \%$, and the negative results are stronger than they appear in table 6. Immigrants' background rates may be lower than national rates, but immigrants contribute only $25 \%$ of the man-years for high and medium grade men.

Early entrants already in service before 1932 at factory A and before 1948 at B are of minor importance in this study. Conditions for these men must certainly have been worse than for later entrants, and yet there is little indication of a lung cancer risk among the high and medium grade early entrants (total $\mathrm{O} / \mathrm{E}$ 5/3.97). This anomaly probably reflects the biased nature of these groups of men, many of whom entered observation long after first exposure and had by definition already survived part of the critical period of 29 years after starting service.

No "healthy worker effect," reducing overall mortality, could be discerned among men entering factory A before 1946 or factory B before 1961 (table 3). As explained, the workforces were relatively unselected, conditions were dusty, and there was probably raised mortality from bronchitis, and up to the dates mentioned lead poisoning was common. At both factories, however, lung cancer mortality continued to be excessive after overt lead poisoning had virtually ceased. At factory $B$ the lung cancer hazard appears as severe among 1961-7 entrants as among earlier workers; in 1968 conditions were improved and a separate zinc chromate department built, but zinc chromate production then increased. By the end of 1982 no lung cancer deaths had occurred among 1968-75 entrants, but follow up totalled only 7-14 years.

At factory A important improvements were made to working conditions in 1955 and preventive measures were more strictly enforced. The absence of excess lung cancer deaths among 1955-63 entrants is not conclusive because numbers are small $(\mathrm{O} / \mathrm{E}$ $2 / 2 \cdot 00$ ), but no further deaths occurred in 1982 and the group had then been followed up for 19-27 years. If future results confirm that these men were not at risk this must be attributed to effective control of exposures, for products and processes did not change in 1955 and production was actually increasing.

Two other groups at factory A appear to have been unaffected by the lung cancer hazard: the 1933-46 short service workers (O/E 6/5.04), and the 1932-54 low exposure grade entrants (O/E 2/ $2 \cdot 69)$. The negative results for these groups suggest that even severe exposure did not cause excess deaths unless it lasted for at least a year, and that low level exposure may not have been hazardous even when prolonged. These two groups have a long follow up; further lung cancer deaths may still occur among them, but because almost all the men have now been observed for at least 30 years it is no longer possible for them to experience the epidemic of early deaths characteristic of the high and medium grade workers.

Judging by the incidence of lead poisoning, working conditions at factory $C$ were probably no better than those at the other factories, and differences in conditions cannot account for the relatively favourable lung cancer mortality at $C$, which appears quite normal even without adjustment for the high local rates. The numbers involved are small, however, and the combined results for all high and medium grade workers entering service before 1967 (O/E $4 / 5.07$, ratio 0.79 ) has a wide confidence interval of $0 \cdot 2-2 \cdot 0$. Continued observation is necessary to confirm the negative results but is so far encouraging, for no further deaths occurred in 1982 . To date the results for factory $\mathrm{C}$ lend no support to the suggestion that exposure to lead chromate may induce lung cancer in man. It would be fruitless to postulate that under worse conditions a risk might operate, for under worse conditions lead poisoning would be rife. In any case, 57 lead poisoned men from all three factories showed only a modest excess of lung cancer deaths $(\mathrm{O} / \mathrm{E} 4 / 2.77)$ considering that many were also exposed to zinc chromate. ${ }^{12}$

Other published studies of chromate pigment workers $^{4-9}$ failed to distinguish workers free from exposure to zinc chromate, though it is reported that unpublished US data similarly found no excess mortality among men exposed only to lead chromate.

Given the apparent absence of a risk at factory $\mathrm{C}$ in this study it seems reasonable to suggest that the hazard affecting workers with mixed exposures at factories $A$ and $B$ (and at factories studied abroad $)^{4^{-9}}$ is attributable to zinc chromate. This suggestion is supported by the Norwegian finding of a severe hazard affecting men with almost exclusive exposure to zinc chromate. ${ }^{56}$ Factory B workers also had slight exposure to strontium chromate, but it cannot be determined whether this increased the hazard, for the lung cancer excess at $B$ is similar to that among 1932-45 entrants at A where strontium chromate was never made.

It is doubtful whether the solitary death from cancer of the nasal sinuses (case 07) is of any significance, and the occurrence of two deaths from laryngeal cancer compared with 0.93 expected could be a chance finding; if factory $\mathrm{C}$ is excluded the $\mathrm{O} / \mathrm{E}$ figures are $1 / 0 \cdot 76$. These findings throw no light on the question of whether the lung cancer hazard at factories A and B extended to other respiratory can- 
cers.

The lung cancer hazard in the English factories is characterised by unusually short latent intervals between first exposure and death almost certainly shorter than those typically found among affected workers in the manufacture of dichromates $(\mathrm{J} M$ Davies and $\mathbf{P}$ Bidstrup, in preparation). If the cessation of excess mortality after 30 years that has been found among 1932-45 entrants at factory A persists in future years this too will be unusual, though not unique. Weiss has described how the epidemic of lung cancers induced by chloromethyl ethers peaks during 15-19 years after the onset of exposure and then begins to subside, and he comments on the rarity of descriptions of the epidemic curves of occupational lung cancers. ${ }^{21}$ Certainly few studies have been able to observe complete entry cohorts for 36 years or longer as done here for the 1932-45 entrants.

Three other published studies ${ }^{4-8}$ provide some data on latent intervals among workers exposed to zinc chromate, though only the Norwegian data ${ }^{56}$ related to a complete cohort; there the shortest interval was 17 years. At the French factory ${ }^{8}$ one 42 year old worker developed lung cancer only four and a half years after first exposure, but the other 13 cases had intervals of at least 12 years. Of the eight German cases described in $1943,{ }^{4}$ two died aged 35 and 42 only seven years after first exposure, and two others after only 11 years. Thus the short intervals characteristic of the English study are not unique, though not replicated in the Norwegian results.

A surprising finding in the present study was that the overall lung cancer excess among men with medium exposure working on wet processes was as great as that among men with high exposure working in dry departments; Frentzel-Beyme ${ }^{9}$ similarly found no difference between the two groups, and he too found no excess among workers with low exposure. Table 8 however, suggests that there may be differing results for high and medium grade workers when duration of service is taken into account, with the mortality of high grade workers apparently worse among those leaving after short exposure. Interestingly, an analysis of mortality from nonmalignant respiratory diseases less pneumonia - that is, deaths mainly from chronic bronchitis and related diseases-among 1932-54 entrants at factory A shows a parallel finding: among high exposure workers there were four such deaths compared with 2.49 expected, but all occurred among men who left after only one year's service $(\mathrm{O} / \mathrm{E} 4 / 1 \cdot 20)$, whereas among medium exposure workers the excess of deaths $(\mathrm{O} / \mathrm{E} 11 / 5.97)$ was confined to those with more than one year's service $(O / E$ 10/4.65). As emphasised, working conditions used to be very dusty, especially in the dry departments; one possible explanation for the apparently anomalous results by duration of service in high exposure workers may be that some men particularly susceptible both to the lung cancer hazard and to other respiratory diseases selected themselves out of exposure after relatively brief employment because they suffered adverse short term respiratory effects from the dusty conditions.

Whatever the explanation for the unusual pattern of deaths by latent interval, exposure grade, and duration of service, it seems clear that at certain dates continuous exposure in wet or dry departments for one year was sufficient to cause lung cancer in some men. The excess mortality found after short service is too pronounced to be explicable merely in terms of the somewhat raised lung cancer mortality that may be found generally in industrial studies among ex-workers who have left employment after short periods of service..$^{22} \mathrm{It}$ is also clear that as a group high and medium grade workers exposed to zinc chromate at factories $\mathrm{A}$ and $\mathrm{B}$ have suffered heavily from occupational lung cancer. Taking numbers of "attributable" (excess) deaths after deducting those expected at national rates, it is found that among 1932-54 entrants at factory $\mathrm{A}$ about one man in 15 has died from occupational lung cancer, with 11 excess deaths among 170 men. Among 1948-67 entrants at factory B the toll has been more severe, with about one man in 11 or 12 affected (10 excess deaths among 115 men, including two deaths in 1982). Direct comparison with the severity of the risks found in chromate pigment factories in other countries is not feasible on account of differing study designs.

This study was sponsored by the Association of European Manufacturers of Lead Chromate Pigments, and was made possible by the wholehearted cooperation of the management of the three factories. The study utilises a computer program developed jointly with $\mathbf{R}$ Tweed; Miss Jean Miller prepared the manuscript and figure. The Institute of Cancer Research receives support from the Medical Research Council and the Cancer Research Campaign. 
Appendix table: details of all lung cancer deaths

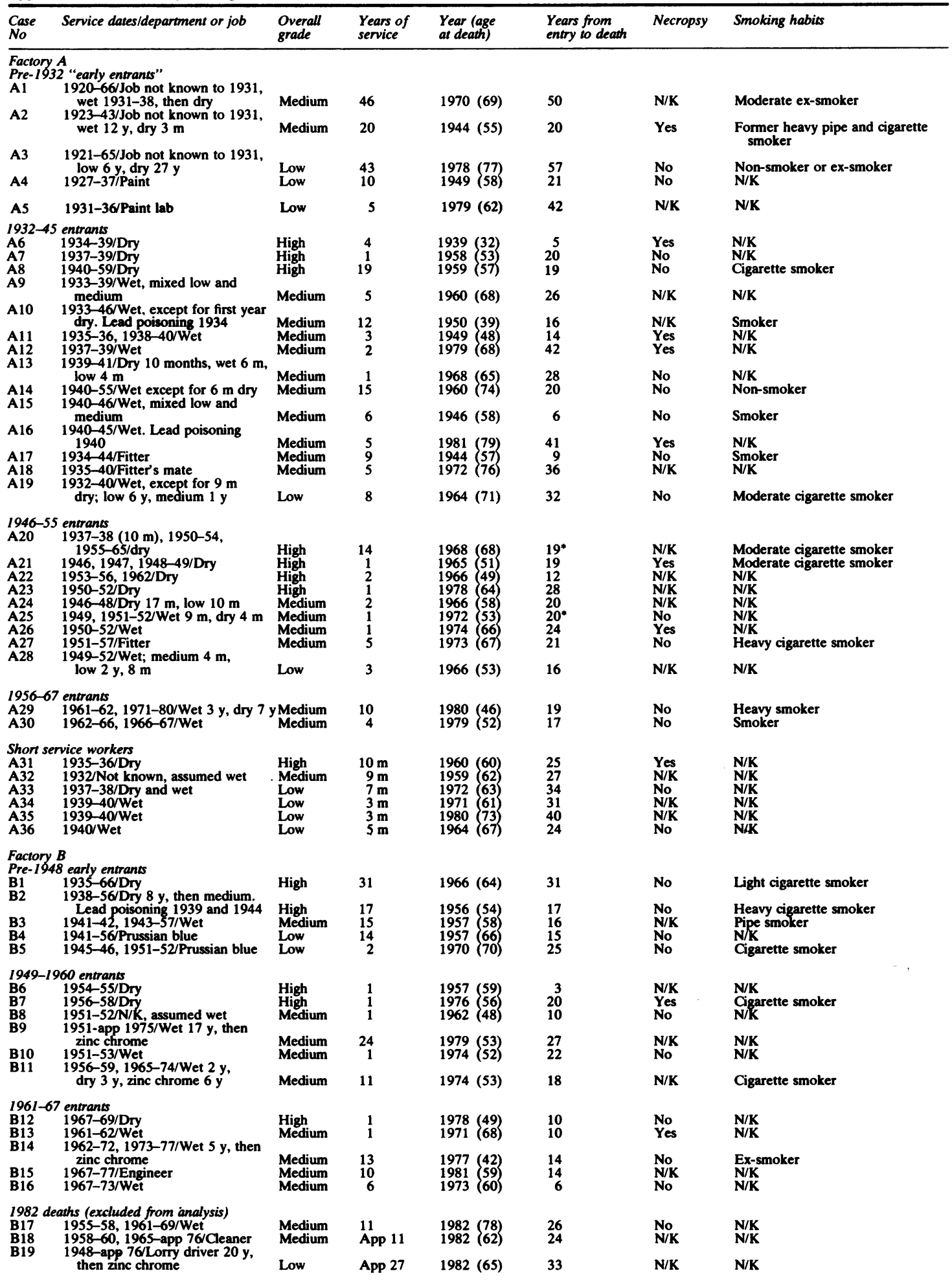


Appendix table: details of all lung cancer deaths

\begin{tabular}{|c|c|c|c|c|c|c|c|}
\hline $\begin{array}{l}\text { Case } \\
\text { No }\end{array}$ & Service dates/department or job & $\begin{array}{l}\text { Overall } \\
\text { grade }\end{array}$ & $\begin{array}{l}\text { Years of } \\
\text { service }\end{array}$ & $\begin{array}{l}\text { Year (age } \\
\text { at death) }\end{array}$ & $\begin{array}{l}\text { Years from } \\
\text { entry to death }\end{array}$ & Necropsy & Smoking habits \\
\hline \multicolumn{8}{|c|}{$\begin{array}{l}\text { Factory } C \\
\text { Pre- } 1946 \text { early entrants }\end{array}$} \\
\hline $\mathrm{Cl}$ & $\begin{array}{l}1930-40,1945-47,1950-52 / \mathrm{Job} \\
\text { to } 1940 \text { not known, thereafter } \\
\text { dry. Lead poisoning } 1937\end{array}$ & High & 14 & $1957(45)$ & 26 & $\mathbf{N} / \mathbf{K}$ & Smoker, not heavy \\
\hline $\begin{array}{l}\mathrm{C2} \\
\mathrm{C} 3 \\
\mathrm{C} 4 \\
\mathrm{C} 5\end{array}$ & $\begin{array}{l}\text { wet } \\
\text { 1938-64/Engineer } \\
1940-58 / \text { Watchman } \\
1941-42,1942-48 / \text { Stoker }\end{array}$ & $\begin{array}{l}\text { High } \\
\text { Medium } \\
\text { Low } \\
\text { Low }\end{array}$ & $\begin{array}{r}7 \\
26 \\
17 \\
6\end{array}$ & $\begin{array}{l}1956(63) \\
1964(61) \\
1962(75) \\
1976(81)\end{array}$ & $\begin{array}{l}12 \\
26 \\
21 \\
34\end{array}$ & $\begin{array}{l}\text { No } \\
\text { No } \\
\text { Yes } \\
\text { Yes }\end{array}$ & $\begin{array}{l}\text { Probable ex-smoker } \\
\text { Heavy smoker (40-60 cigs) } \\
\text { Pipe smoker } \\
\text { Smoker }\end{array}$ \\
\hline $\begin{array}{l}1946 \\
\mathrm{C} 6 \\
\mathrm{C} 7\end{array}$ & $\begin{array}{l}967 \text { entrants } \\
1954-70 / \text { Fitter } \\
1948-61 / \text { Stoker }\end{array}$ & $\begin{array}{l}\text { Medium } \\
\text { Low }\end{array}$ & $\begin{array}{l}15 \\
12\end{array}$ & $\begin{array}{l}1972(71) \\
1961(62)\end{array}$ & $\begin{array}{l}17 \\
12\end{array}$ & $\begin{array}{l}\text { No } \\
\text { Yes }\end{array}$ & $\begin{array}{l}\text { Smoker } \\
\text { Smoker }\end{array}$ \\
\hline $\begin{array}{l}\text { Other } \\
\text { Lung } \\
\text { O1 } \\
\text { O2 } \\
\text { O3 }\end{array}$ & $\begin{array}{l}\text { ases } \\
\text { ancer mentioned on death certificate or } \\
\text { Factory A } 1935-36 / \text { Wet } \\
\text { Factory A } 1939-40 / \text { Low } \\
\text { Factory A } 1951-52 / \text { Dry and wet }\end{array}$ & $\begin{array}{l}\text { only as a co } \\
\text { Medium } \\
\text { Low } \\
\text { Medium }\end{array}$ & $\begin{array}{l}\text { ibutory cau } \\
8 \mathrm{~m} \\
4 \mathrm{~m} \\
1\end{array}$ & $\begin{array}{l}\text { (excluded fro } \\
1982(76) \\
1978(68) \\
1981(59)\end{array}$ & $\begin{array}{l}\text { nalysis) } \\
46 \\
38 \\
30\end{array}$ & $\begin{array}{l}\text { N/K } \\
\text { Yes } \\
\text { Yes }\end{array}$ & $\begin{array}{l}\mathbf{N} / \mathbf{K} \\
\mathbf{N} / \mathbf{K} \\
\mathbf{N} / \mathbf{K}\end{array}$ \\
\hline $\begin{array}{l}\text { Excluc } \\
04\end{array}$ & $\begin{array}{l}\text { ed worker at factory } C \text { dying from lun } \\
\text { Factory C 1961-63/Dry foreman } \\
\text { Another factory app 1946-61/ } \\
\text { dry chargehand on zinc chromate }\end{array}$ & $\begin{array}{l}\text { ng cancer } \\
\text { High } \\
\text { e High }\end{array}$ & $\begin{array}{l}1 \\
\text { App } 15\end{array}$ & $1963(43)$ & $\begin{array}{l}1 \\
\text { App } 17\end{array}$ & No & Probable smoker \\
\hline $\begin{array}{l}\text { Death } \\
\text { O5 } \\
\text { O6 }\end{array}$ & $\begin{array}{l}\text { from larynx cancer } \\
\text { Factory A } 1919-48 / \text { Cooper } \\
\text { Factory C } 1959-63 / \text { Wet }\end{array}$ & $\begin{array}{l}\text { Low } \\
\text { Medium }\end{array}$ & $\begin{array}{r}29 \\
4\end{array}$ & $\begin{array}{l}1948(62) \\
1977(52)\end{array}$ & $\begin{array}{l}48 \\
17\end{array}$ & $\begin{array}{l}\text { Yes } \\
\text { No }\end{array}$ & $\begin{array}{l}\mathbf{N} / \mathbf{K} \\
\mathbf{N} / \mathbf{K}\end{array}$ \\
\hline $\begin{array}{l}\text { Death } \\
\text { O7 }\end{array}$ & $\begin{array}{l}\text { om cancer of frontal sinus } \\
\text { Factory A } 1935-37 / \text { Fitter }\end{array}$ & Medium & 2 & $1942(53)$ & 7 & No & $\mathbf{N} / \mathbf{K}$ \\
\hline
\end{tabular}

"In cases of broken service "entry" is taken as 1 year before the date when 365 days' service is completed.

\section{References}

' Hayes RB. Cancer and occupational exposure to chromium chemicals. In: Lilienfeld AM, ed. Reviews in cancer epidemiology. Vol 1. Elsevier/North Holland: New York, 1980.

${ }^{2}$ International Agency for Research on Cancer. Monographs on the evaluation of the carcinogenic risk of chemicals to humans. Vol 23. Some metals and metallic compounds. Lyon: IARC 1980.

${ }^{3}$ Baetjer AM. Pulmonary carcinoma in chromate workers. 1. A review of the literature and report of cases. Archives of Industrial Hygiene and Occupational Medicine 1950;2:487-504.

- Gross E, Kolsch F. Uber den Lungenkrebs in der Chromfarbenindustrie. Archives fur Gewerbepathologie und Gewerbehygiene 1943;12:164-70.

s Langard S, Norseth T. A cohort study of bronchial carcinoma in workers producing chromate pigments. $\mathrm{Br} J$ Ind Med 1975;32:62-5.

- Langard S, Vigander T. Occurrence of lung cancer in workers producing chromium pigments. $B r J$ Ind Med 1983;40:71-4.

' Sheffet A, Thind I, Miller AM, Louria DB. Cancer mortality in a pigment plant utilizing lead and zinc chromates. Arch Environ Health 1982;37:44-52.

- Haguenoer JM, Dubois G, Frimat P, Cantineau A, Lefrancois H, Furon D. Mortalité par cancer broncho-pulmonaire dans une fabrique de pigments a base de chromates de plomb et de zinc. In: Prevention of occupational cancer. International Symposium. (Occupational Safety and Health Series No 46.) Geneva: International Labour Office, 1981:168-76.

- Frentzel-Beyme R. Lung carrer mortality of workers employed in chromate pigment factories. J Cancer Res Clin Oncol 1983;105: 183-8.
${ }^{10}$ Davies JM. Lung cancer mortality of workers making chromate pigments. Lancet 1978; 384.

" Davies JM. Lung cancer mortality of workers in chromate pigment manufacture: an epidemiological survey. Journal of the Oil and Colour Chemists Association 1979;62:157-63.

12 Davies JM. Long term mortality study of 57 chromate pigment workers who suffered lead poisoning. $\mathrm{Br} J$ Ind Med 1984;41:170-8.

${ }^{13}$ International classification of diseases. 9th rev. Geneva: World Health Organisation, 1977.

14 Bailar JC, Ederer F. Significance factors for the ratio of a Poisson variable to its expectation. Biometrics 1964;20:639-63.

15 Office of Population Censuses and Surveys. Occupational mortality, England and Wales 1970-2. London: HMSO, 1978:51. (Series DS No 1.)

${ }^{16}$ Registrar General. Decennial supplement, England and Wales, 1951. Occupational mortality. Vol 2. London: HMSO, 1958. Table 3A (i).

${ }^{17}$ Registrar General. Decennial supplement, England and Wales, 1961. Occupational mortality tables. London: HMSO, 1971.

18 Registrar General. Decennial supplement, England and Wales, 1951. Area mortality. London: HMSO, 1958.

19 Registrar General. Decennial supplement, England and Wales, 1961. Area mortality tables. London: HMSO, 1967.

${ }^{20}$ Office of Population Censuses and Surveys. Area mortality tables 1969-1973, England and Wales. London: OPCS, 1979. (Series DS No 3. Microfiche tables.)

${ }^{21}$ Weiss W. Epidemic curve of respiratory cancer due to chloromethyl ethers. JNCI 1982;69:1265-70.

${ }^{22}$ Fox AJ, Collier PF. Low mortality rates in industrial cohort studies due to selection for work and survival in the industry. Br J Prev Soc Med 1976;30:225-30. 